\title{
NANCY NATURAL RADIOCARBON MEASUREMENTS 1
}

\author{
R. COPPENS, G. L. A. DURAND, and B. GUILLET
}

Cientre de Recherches Radiogéologiques, Nancy-Vandoeuvre, $54 \mathrm{~F}$

This paper is a list of the first results of age determinations made at the Cientre de Recherches Radiogéologiques de Nancy (CRR). The Cienter is the result of a convention between the Commissariat à l'Energie Atomique (CEA) and the University of Nancy. It is part of a group of research laboratories of Earth Sciences headed by Prof. M. Roubault.

\section{INTRODUCTION}

The creation of a Natural Radiocarbon Laboratory was decided in 1960. The installation was completed in the new laboratories of the C.R.R. in 1961. A modification of the system for gas preparation and for counter filling was made in 1962 after calibrations had shown the poor quality of $\mathrm{CO}_{2}$ obtained with the first equipment. In 1963 we spent the year in calibrations and checking measurement reproducibility. The first useful results were obtained in 1964 after improvement of the electronic system. In 1965 B. Guillet was able to present his "thèse de 3ème Cycle" on the "Datation of the Beillard peatbog."

All measurements were made in a cylindrical proportional counter, $70 \mathrm{~mm}$ in diameter and $310 \mathrm{~mm}$ long, the stainless steel wall of which makes the ground cathode.

The nickel central wire of $.05 \mathrm{~mm}$ set in the axis of the counter is the anode brought to a positive potential of $5400 \mathrm{v}$. The counter has a capacity of $1,16 \mathrm{I}$. and is normally filled with $\mathrm{CO}_{2}$ under a pressure of $736 \mathrm{~mm}$ of mercury. The counter, permanently set inside a lead shield, is connected by copper tubing, $20 \mathrm{~mm}$ in diameter, to a pumping system (rotary and mercury diffusion pumps with liquid nitrogen traps). The vacuum level inside the counter is directly determined as follows: the anodic tension is maintained cluring the pumping, the change of the discharge between the anode and the cathode is examined as the vacuum becomes better. For this purpose an oscilloscope is connected to the output of the counter. Previous calibration determines the exact vacuum level. At discharge extinguishment, the vacuum is better than $10^{-5} \mathrm{~mm}$ of mercury.

The proportional counter is shielded by $20 \mathrm{~cm}$ of lead and covered by a bismuth shroud and layers of paraffin and boric acid (de Vries, 1957). Anticoincidence shielding is provided by 36 Geiger-Muller tubes surrounding the sample counter. The signal given by the counter is first amplified and then, after discrimination and anticoincidence, directed to 3 counting channels. We work with 3 discriminating thresholds corresponding to signals of 10,15 , and $25 \mathrm{mv}$ at the input of the amplifier. This system provides 3 different counting results, giving 3 ages for the same sample. As a rule, these ages are almost identical in the case of a good measurement but are very different in the case of a mistake in the manipulation of the sample. 
$\mathrm{COO}_{2}$ is prepared according to the method described by Rafter (1953): burning the sample in oxygen, bubbling the gas in a soda solution and transforming the obtained sodium carbonate into $\mathrm{Ba} \mathrm{CO}_{33}$ with $\mathrm{Ba} \mathrm{Cl}_{\text {., }}$ which is then stored. Sulfuric acid is used to liberate $\mathrm{CO}_{2}$ from the $\mathrm{Ba} \mathrm{CO}_{3}$. The $\mathrm{CO}_{2}$ is purified on alumina and by fractional crystallization. After purification, the gas is stored in flasks for more than 30 days to eliminate the radon that may result from impurity of the reagents.

Filling of the proportional counter is made at the fixed pressure of $736 \mathrm{~mm}$ of mercury. Before each measurement, the occurrence of impurities in the gas is verified by measuring the activity of an external source (Pitchblende) placed at a given distance. The working voltage is adjusted accordingly.

The modern relerence sample is a growth ring, dated from 1930, of a stem of Douglas fir (Pseudotsuga Douglasii) felled in 1956, grown in Provence far from any industrial area. We expect to use standard NBS oxalic acid very soon. Average values of measures made on the modern sample are reported here; 12,88 dpm, 12,07 dpm, 10,74 dpm.

The measurements of the background were made by using industrial CO.. delivered in bombs and coming from cokeovens. The average values are: $7.48 \mathrm{dpm}, 7.11 \mathrm{dpm}, 6,47 \mathrm{dpm}$. The values for the "background" and for the "living sample" mentioned here correspond to the average results obtained with the values of the discriminating thresholds mentioned. The quality of the industrial CO.2 was tested in comparison with CO.. prepared from a calcite found in druse in an outcrop of portlandian limestone of the "Cotes de Meuse." The background obtained with this gas is: $7,57 \mathrm{dpm}, 7,15 \mathrm{dpm}, 6.48 \mathrm{dpm}$. All samples were counted for 2.1 hrs and the period of radiocarbon used in the calculation is $5.560 \pm 30$ yrs.

\section{ACKNOWLADGNETS}

The apparatus was built and calibrated by Prol. (;. Durand according to the instructions of J. Laberrie and (;. Delibrias from the Saclay Lab. to whom we express our acknowleclgments. We also thank the scientists who have permitted us to publish the results obtained on samples submitted to this laboratory.

\section{S.MMPLE DES(IRIPTIONS}

1. GIOLOGIC: SAMHPIAS

\section{Ny-11. Mercy le Bas, Mainbotel, Meurthe-et-Moselle}

1850 B.C.

Peat from the "vallice de la Crusnes" at Mainbotel (49²9" $593^{\circ} \mathrm{N}$

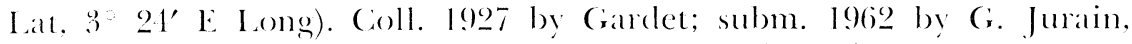
Faculte des Sciences. Nancy. Comment: palynologic study of sample shows Fagus-Abies with Almus. Conylus, and Pimus of the Sub-Boreal or SubAtlantic period. 


\section{Le Beillard series, Vosges}

Sphagnum peats at Le Beillard near Gerardmer in the Cileuric valley $\left(48^{\circ} 05^{\prime} \mathrm{N}\right.$ Lat, $1^{\circ} 28^{\prime} \mathrm{E}$ Long) overlying glacial deposits. Pollen analyses of these peats were made by B. Guillet (1965). Coll. 1962 and subm. 1963 by B. Guillet. Depth in cm from surface is given in each heading.

Ny-28. Le Beillard, $30 \mathrm{~cm}$

$4110 \pm 230$

Fibrous peat with pollen of (Duerus, Tilia, Corylus, without Fagus

\section{Ny-29. Le Beillard, $160 \mathrm{~cm}$}

$\mathbf{7 5 5 0} \pm \mathbf{3 5 0}$

Fibrous yellowish brown peat with Quercus, Tilia, Ulmus pollen.

\section{Ny-30. Le Beillard, $180 \mathrm{~cm}$}

$\mathbf{7 6 8 0} \pm \mathbf{3 7 0}$

Compact peat with pollen of Pimus, Betula, and Corylus.

\section{Ny-31. Le Beillard, $200 \mathrm{~cm}$}

$8310 \pm 370$

Compact peat; beginning of Corylus indicates Boreal period.

\section{Ny-32. Le Beillard, $210 \mathrm{~cm}$}

$8060 \pm 440$

Sandy peat with Pinus overlying glacial sand.

General Comment: peaty lormation begins in Boreal period with Pinus, Betula, and Corylus. During Atlantic period, from $160 \mathrm{~cm}$ to the surlace. peat growth was very rapid. The $4110 \pm 290$ level (Ny-28) is contaminated by present roots.

\section{Yy-12. Geological Survey of Canada}

$$
12,450 \pm 460
$$
10,500 B.c.

Wood (GSC; 1) subm. 1964 by W. Dyck for inter-laboratory calibration. Comparison of results given by other laboratories:

Lamont Geological Observatory

Isotopes, Inc.

C.S.C. Laboratory

Nancy Radiocarbon Laboratory

$$
\begin{aligned}
& 12,150 \pm 250 \\
& 12,000 \pm 400 \\
& 12,400 \pm 200 \\
& 12,450 \pm 460
\end{aligned}
$$

\section{Vy-53. Belle-Ile-en-Mer, Morbihan}

$$
2890 \pm 230
$$

Peat from top of "Anse de Ster wras" peat bog; $\left(46^{\circ} 55^{\prime} 20\right)^{\prime \prime}$ N Lat, 5 :55 10" W Long). Coll. and subm. 1964 by Y'. Cioppens. Comment: lated by Radiocarbon Laboratory of Saclay at 730 B.(C. (unpub.).

\section{Yy-6.5. Anloa, Cameroun}

I.ignite in argillaceous sand rith vivianite from Anloa from valles of Margol river ( $7028^{\prime \prime} \mathrm{N}$ Latt. $13^{\circ} 25^{\prime} 42^{\prime \prime} \mathrm{E}$ Long). Coll. and subm. l96, by J. Sarcia. Burcau de Rech. Géol. et Min., Paris. 


\section{Saint-Gilles series}

Dates of 3 Post-Wurmian peat layers of the Camargue sediments between Arles, Beaucaire, and Saint-Gilles. Coll. by A. Bonnet and subm. 1966 by H. Alimen, Lab. Géol. Quat. CiNRS, Paris.

Ny-71. Chemin coté, 0,9

$1110 \pm 200$

Fen peat coll. at $-3 \mathrm{~m}$ in "Chemin coté $0,99^{\prime}$ boring $\left(43^{\circ} 40^{\prime} 15^{\prime \prime} \mathrm{N}\right.$ Lat, $2^{\circ} 5^{\prime} 50^{\prime \prime}$ E Long).

Ny-69. Chemin de Halage, $-7 \mathrm{~m}$

$4550 \pm \mathbf{3 4 0}$

Fen peat coll. at $-7 \mathrm{~m}$ in the "Chemin de Halage" boring $\left(43^{\circ} 40^{\prime}\right.$ $20^{\prime \prime} \mathrm{N}$ Lat, $2^{\circ} 5^{\prime} 45^{\prime \prime} \mathrm{E}$ Long).

\section{Ny-70. Chemin de Halage, $-9 \mathrm{~m}$}

Fen peat coll. at $-9 \mathrm{~m}$ in the "Chemin de Halage" boring. General Comment: by dating these 3 peat horizons, A. Bonnet, 1966, was able to make precise studies on the stratigraphy and chronology of sedimentation in the Rhone delta in Ciamargue.

\section{ARCiHAEOLOGIC: SAMPLES}

\section{Ny-4. Richardmenil, Meurthe-et-Moselle}

$4280 \pm 350$

\section{B.C.}

Trunk of oak in sand of the Moselle river near Richardmenil $\left(48^{\circ}\right.$ $35^{\prime} \mathrm{N}$ Lat, 3 50' E Long). Coll. 1960 and subm. 1962 by G. Vaucel, ENSG, Nancy. Comment: dated in 1960 by Radiocarbon Laboratory of Saclay at $4270 \pm 300$ (G. Vaucel, 1960).

\section{Ny-6. Saint-Gildas de Rhuys, Morbihan}

$2290 \pm 270$

340 B.C.

Charcoal found near the "four à augets" No. 16 of the 1964 inventory, on the Saint Gildas de Rhuys beach $\left(47^{\circ} 29^{\prime} 20^{\prime \prime} \mathrm{N}\right.$ Lat, $5^{\circ} 10^{\prime} 15^{\prime \prime} \mathrm{W}$ Long). Subm. 1964 by Y. Coppens, Museum Hist. Nat., Paris. Comment: "four à augets" was probably used by Celtic people of Brittany in the salt industry.

\section{Ny-15. Pierre la Treiche, Meurthe-et-Moselle}

$7950 \pm \mathbf{5 3 0}$ 6230 B.C.

Dorsal vertebra of Ursus spelaeus found in the Sainte Reine cave at Pierre la Treiche near Toul (48 $39^{\prime} \mathrm{N}$ Lat, $3^{\circ} 35^{\prime} \mathrm{E}$ Long). Sample from the collection of the ENSG Museum. Coll. 1865 by P. Husson. Comment: a complete description of the Sainte Reine cave is given by P. Husson (1865) who identified abundant mammals.

\section{Ny-67. Bassin du Tchad}

2290 B.C.

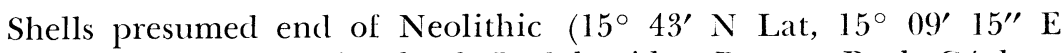
Long). Coll. and subm. 1966 by S. L. Schneider, Bureau Rech Gíol. et Min., Fort Lamy, Tchad. 
Ny-68. Bassin du Tchad

Shells presumed of Lacustrian Neolithic (15 $17^{\prime} 30^{\prime \prime} \mathrm{N}$ Lat, $19^{\circ} 01^{\prime}$ 30" E Long). Coll. and subm. 1966 by J. L. Schneider (in press).

Ny-74. Bassin du Tehad

Modern

Fish-bones from terminal Lacustrian sediments in "Pays Bas of Tchad." ( $16^{\circ} 41^{\prime} 30^{\prime \prime} \mathrm{N}$ Lat, $18^{\circ} 11^{\prime} 15^{\prime \prime} \mathrm{E}$ Long). Coll. and subm. 1966 by J. L. Schneider. Comment: fishes presumed older than few hundred vis.

Ny-73. Jebel Irhoud, Morocco

Bones of mammals from upper layer of Jebel Irhoud cave $\left(31^{\circ} 53^{\prime}\right.$ $34^{\prime \prime} \mathrm{N}$ Lat, 8 $8^{\circ} 51^{\prime} 38^{\prime \prime} \mathrm{W}$ Long). Coll. 1962 and subm. 1966 by Prof. E. Ennouchi, Faculté des Sciences, Rabat, Maroc. Comment: remains of two Homo neanderthalensis were found in this layer with a classic Mousterian industry and about 3000 bones of various animals (E. Ennouchi, 1962).

\section{Ny-76. Ain Boucherit, Saint Arnaud, Algeria}

$\mathbf{5 1 2 0} \pm \mathbf{3 1 0}$ cherit ( $36^{\circ} 11^{\prime} 34^{\prime \prime} \mathrm{N}$ Lat, $5^{\circ} 45^{\prime} 11^{\prime \prime}$ E Long). Coll. and subm. 1966 by Prof. C. Camps, Faculté des Lettres et Sciences Humaines, Alger. Comment: expected age 5050 to 6050 B.C. would date a particular level of Upper Capsian in Algeria.

1)ate lists:

REFERENCES

$\begin{array}{ll}\text { GSC I } & \text { Dyck and Fyles, } 1962 \\ \text { Isotopes I } & \text { Walton, Trautman, and Friend, } 1961 \\ \text { Lamont V } & \text { Olson and Broecker, 1959 } \\ \text { Saclay I } & \text { Delibrias, Guillier, and Labeyric, 1964 }\end{array}$

Bonnet. 1., 1966, Structure de la Camargue entre Arles, Beaucaire, et Saint-Gilles du Gard: C.Rsom. Soc. Géol. de France, v. 7, p. 258-259.

Delibrias, (;. and Perquis, M. I., 1958, Datage par la mćthode du 14-C, BIST du C.E.A: no. 21, p. 1013.

Ennouchi, E.. 1962, Un Near.terthalien: l'homme du Jebel Irhoud: L'Anthropologie, v. 66, no. $3-4$, p. $279-299$.

Cinillet, B., 1965, La méthode de datation par le 14-C. Application à la détermination de l'âge de la Tourbière du Beillard: Thèse 3e Cycle, Nancy.

Schneider, J. I.., 1966, Rapport de synthèse de la carte hydrogéologique de reconnaissance Mao, au 1/500000, Thad, BRGM, Fort Lamy.

Vaucel, G., 1960, Contribution à l'étude géologifue de la région de Bayon: DES, Nancy, $59 \mathrm{p}$

de V'ries, H., 1957, Further analysis of the neutron component of the background of counters used for 14-C. age measurements: Nuclear Physics, v. 3, p. 65. 